\section{USE OF BiOLOGICAL INDICATORS IN TMDL ASSESSMENT AND IMPLEMENTATION}

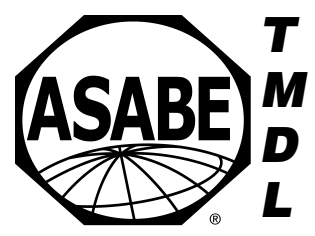

\author{
G. Yagow, B. Wilson, P. Srivastava, C. C. Obropta
}

\begin{abstract}
Most states in the U.S. have a general water quality standard intended to protect water from all potential pollutants not specifically named or identified in other standards. Biological indicators are used, in part, to assess the level of water quality with respect to this general standard. Under EPA's Total Maximum Daily Load (TMDL) program, impaired waters based on a biological assessment require an additional step compared with non-biological TMDLs. In non-biological TMDLs, the "pollutant" is typically the parameter being monitored, with a direct link to the impairment. In biological TMDLs, cause and effect must first be established between one or more pollutants and the impacted biological community. This article presents examples of approaches taken in different states to monitor and assess the biological health of our streams based on varying combinations of algal, macroinvertebrate, and fish communities. While fish are the ultimate integrator of lower ecological organisms, their occurrence and abundance has been greatly manipulated by humankind. Periphytic algae are perhaps the fastest responding biological population and can be used for some pollutant-specific diagnoses, but most states lack the expertise required for detailed taxonomic classification. Macroinvertebrates, the most commonly monitored biological community, are abundant in most streams, but most metrics are not diagnostic of specific stressors. Within the TMDL framework, issues are discussed related to setting TMDL targets, linking biological impairments with pollutants, and defining biological target endpoints. Although surrogate measures are often used for setting TMDL target loads, biological recovery is measured against biological endpoints. The use of biological indicators for assessment and development of biological TMDLs can be improved through modeling procedures that better define cause-and-effect relationships, through a better understanding of the limits of restoration, and through a more unified national policy that focuses on restoration.
\end{abstract}

Keywords. Algae, Benthic macroinvertebrates, Bioassessment, Biological indicator, Fish, Periphyton, Stressor analysis, TMDL, Water quality, Watershed.

B iological communities have been shown to be useful indicators of general water quality (Plafkin et al., 1989; Barbour et al., 1999). Water quality standards have been established in all states to define acceptable levels of water quality. However, since it is not possible to proactively identify and quantify levels of all potential pollutants, most states have a general, narrative Aquatic Life Use (ALU) water quality standard whose purpose is to protect waters in the state from all pollutants not specifically identified in other state standards (EPA, 2002a). The U.S. Environmental Protection Agency's (EPA) Total Maximum Daily Load (TMDL) program was developed to identify and restore beneficial uses of our nation's waters where impairment is assessed by comparing monitoring re-

Submitted for review in February 2006 as manuscript number SW 6353; approved for publication by the Soil \& Water Division of ASABE in June 2006.

The authors are Gene Yagow, ASABE Member Engineer, Research Scientist, Department of Biological Systems Engineering, Virginia Tech, Blacksburg, Virginia; Bruce Wilson, ASABE Member Engineer, Professor, Department of Biological and Agricultural Engineering, University of Minnesota, St. Paul, Minnesota; Puneet Srivastava, ASABE Member Engineer, Assistant Professor, Department of Biosystems Engineering, Auburn University, Auburn, Alabama; and Christopher C. Obropta, Assistant Professor, Department of Environmental Sciences, Rutgers, The State University of New Jersey, New Brunswick, New Jersey. Corresponding author: Gene Yagow, Department of Biological Systems Engineering, 307 Seitz Hall, Virginia Tech, Blacksburg, VA 24061; phone: 540-231-2538; fax: 540-231-3199; e-mail: eyagow@vt.edu. sults with the applicable water quality standards (see MuñozCarpena et al., 2006, for more detail).

Biological monitoring, or biomonitoring, is therefore used as an integrator of various stressors that provides valuable information about the overall integrity of a water body. While chemical monitoring is conducted to support established water quality criteria and some priority pollutants, chemical monitoring alone cannot ensure that all pollutants and interactions among them are meeting water quality goals. Biological organisms serve not only as useful indicators of current conditions, but also of cumulative effects and changes over time. Since chemical water quality data are typically measured on a monthly or quarterly basis, the frequency of collected water quality data does not allow for an accurate, scientific comparison of the water quality standards with the monitored data. As Novotny (2003) suggests, daily data must be collected to adequately assess water quality using current water quality standards. Pollution events or levels not detected by infrequent chemical data collection can be captured by biological monitoring. Biological indicators, therefore, are important for identifying problems otherwise missed or underestimated by chemical monitoring, and they constitute a class of response indicators closest in hierarchy to the desired outcomes related to ecological health (Karr and Yoder, 2004).

Biomonitoring consists of sampling and classifying specific biological communities, or assemblages, in and around the stream ecosystem. Bioassessment is the analysis of biomonitoring results over a period of time to determine 
Table 1. Major differences between biological and pollutant-based TMDLs.

\begin{tabular}{lll}
\hline TMDL Component or Procedure & Biological TMDLs & Pollutant-Based TMDLs \\
\hline Assessment of impairment & Biological monitoring and assessment & Ambient physical/chemical monitoring and assessment \\
Applicable standard & Aquatic life use general standard & Pollutant-specific water quality standard \\
Identification of pollutant & Weight-of-evidence stressor analysis & Implicit in the standard \\
Identification of TMDL target & Reference watershed load or biological metric threshold & Pollutant load \\
Load quantification & Reference watershed approach or non-load target & Modeling \\
TMDL endpoint & Recovery of biological community & Load reduction to TMDL target or compliance with stan- \\
& & dards concentration criteria \\
\hline
\end{tabular}

whether a water body supports its designated uses (e.g., meets its ALU standard) by considering shifts in distribution and/or abundance of assemblage species from that of a normal, healthy community for a given region. The ALU standard in Virginia is typical of those in many states, stating in part, "state waters, including wetlands, shall be free from substances ... which ... interfere directly or indirectly with designated uses of such water or which are inimical or harmful to human, animal, plant, or aquatic life" (VAC, 2005). In 2002, forty states used bioassessment to determine support for their ALU, while six states were in the process of developing statewide procedures (EPA, 2002a).

The other articles in this ASABE TMDL modeling series present procedures and tools that are used for developing pollutant-specific TMDLs (e.g., nutrient, sediment, bacteria). In contrast, this article examines the current state of knowledge in developing TMDLs when impairment is revealed, not through the monitoring of a specific pollutant, but through bioassessment. A summary of major differences between biological TMDLs and pollutant-based TMDLs is presented in table 1.

The specific objectives of this article are to present an overview of the commonly used biomonitoring, bioassessment, and stressor identification procedures and models; to discuss how these tools are currently used within the TMDL framework; and to identify the shortcomings of the current procedures and models along with needed improvements.

\section{CurRent ToOls For BIOASSESSMENT AND ANALYSIS}

Some combination of the three major freshwater biological communities (i.e., algae, macroinvertebrates, and fish) is monitored as part of biological assessment in all states. Monitoring typically consists of the collection of stream organisms and then performance of a taxonomic classification of these organisms. Biological assessments of monitored data from each of these biological communities have much in common. These commonalities are discussed, followed by a detailed description of the assessment tools and the strengths and weaknesses of bioassessment based on each community.

\section{Commonality Among Tools}

Characteristics of each community assemblage are represented through a variety of measures or metrics that ideally are tied directly to human influences. EPA has developed lists of potential metrics that can be used to assess richness/abundance, composition, pollution tolerance, and trophic/habit (behavior) characteristics of each biological community (Barbour et al., 1999). Although individual species will vary from region to region, the structure and function of the various communities are similar, allowing for comparisons of results from different regions. Typically, a select set of these metrics are integrated into a single index, which is then scored against a reference scale to determine the health of the stream.

The Rapid Bioassessment Protocols (RBP) comprise a widely used methodology for bioassessment and analysis (Plafkin et al., 1989; Barbour et al., 1999). This methodology evaluates a reach by comparing its results to that of a similar, non-impaired regional reference stream reach. Identification of appropriate reference stream reaches is difficult in some regions. Consequently, several states have recently developed indices based on scoring against a composite set of reference conditions, which thereby provides more uniform criteria for measuring stream health (Tetra Tech, 2003). Proper application of RBP usually requires that the specific set of metrics and the weighting of each metric be calibrated to state or regional conditions (Plafkin et al., 1989; Barbour et al., 1999). Because of this calibration step, a wide variety of biological index configurations based on RBP exists among the states.

As part of the RBP, a visual habitat assessment of the stream corridor is performed in conjunction with biological community sampling, which can provide valuable information to assist in the interpretation of biological community data (Barbour et al., 1999). In 2001, all states reported performing habitat assessments as part of their bioassessment (EPA, 2002a).

One common attribute of all types of bioassessment is that they are responsive to a wider range of pollutants and stressors than is usually monitored in the suite of physical and chemical parameters in state ambient water quality monitoring programs. Contrasted with lower hierarchical effectsbased chemical monitoring, the biological assemblages are response indicators that directly measure the biological health of the stream.

\section{Algal Community Assessment}

Periphyton are benthic algae that are attached to aquatic substrates and are the primary producers in most freshwater environments. Periphytic algae include diatoms (Bacillariophyta), green algae (Chlorophyta), and blue-green algae (Cyanobacteria), and can be found attached to plants, rocks, and within bottom sediments (Crumpton, 1989; NMNH, 2006). As of 2002, approximately twenty states assessed the periphyton community in addition to the benthic macroinvertebrate community as part of their biological assessments (EPA, 2002a). Periphyton sampling methods include combinations of: (1) field rapid assessment surveys, (2) laboratory classification of diatoms and/or soft algae, (3) sub-sampling and analysis of chlorophyll $a$, and/or (4) determination of algal biomass.

Two general types of metrics are used in periphyton assessment: those that characterize biotic integrity (and 
therefore, impairment), and those that diagnose causes of impairment (Barbour et al., 1999). The RBP lists nine possible biotic integrity metrics and seven diagnostic metrics for periphyton (Barbour et al., 1999).

Currently there is much interest in the use of periphyton indices to assist in the development of water quality criteria for nutrients, which are a determining factor in biological community health. Several studies have shown periphyton sampling to be dominated by diatoms (Ambrose et al., 2004; Ponader and Charles, 2003). Diatoms, including such genera as Achnanthes, Navicula, and Nitzschia, are single-celled microscopic plants generally attached to a substrate by a gelatinous extrusion or joined to each other in chains of varying length. Diatoms usually greatly outnumber the soft-algae species, especially in substrate-limited streams with flow velocities greater than $10 \mathrm{~cm} / \mathrm{s}$, plenty of light, and low nutrients (NWCC, 1999).

Some of the most commonly used periphyton indices are based solely on diatom metrics. Ponader and Charles (2003) evaluated twelve diatom indices widely used in Europe and found that three of them, the Trophic Diatom Index (Kelly, 1998), the Biological Diatom Index (Prygiel and Coste, 1999), and the Specific Polluosensitivity Index (Prygiel et al., 1996), correlated well with phosphorus concentrations and, therefore, appeared to have potential for use in New Jersey for assessing nutrient enrichment. New Jersey eventually developed diatom total nitrogen (TN) and total phosphorus (TP) indices based on the results of weighted-average partial least squares inference models (Ponader et al., 2006). Hill et al. (2000) created a periphyton index of biotic integrity (PIBI) based on algal genera richness; the relative abundances of diatoms, Cyanobacteria, dominant diatom genus, acidophilic diatoms, eutraphentic diatoms, and motile diatoms; chlorophyll and biomass (ash-free dry mass) of standing crops; and alkaline phosphatase activity. A later study of 272 eastern U.S. rivers and streams resulted in a PIBI, also based primarily on diatoms, that included the above metrics with the addition of metrics for percent acidobiontic diatoms, percent eutraphentic diatoms, and percent motile diatoms (Hill et al., 2003). In Florida, three periphyton suitability indices (PSI) were developed, all based on hydroperiod, i.e., the typical time period that an area is subject to continuous flooding. These algal indices are specific for attached benthic communities (BPSI), floating communities (FPSI), and for submerged epiphyton communities (EPSI). The choice of index for a given area is based on a combination of the following factors: percent of each community comprising total biomass, percent organic content of the floating mat, percent non blue-green algae, percent areal cover of the floating mat, and the abundance of submerged macrophytes (Gaiser et al., 2004). Griffith et al. (2002) assessed relationships between periphyton assemblages and environmental gradients in the Southern Rockies ecoregion to identify metrics that might be useful for creating a periphyton index and be diagnostic of larger-scale stressors in this ecoregion. Therefore, many variations of periphyton indices have been created and are in use across the country.

A major strength of algal community indicators is that they respond rapidly to environmental change because of their short lives and rapid reproduction rates. Changes in physical and chemical characteristics most directly affect these primary producers. Sampling of the algal community creates minimal disturbance to the resident benthic biota, and standard evaluation methods exist for non-taxonomic measurements (e.g., biomass, chlorophyll $a$ ). Indices developed for periphyton also do not appear to be significantly influenced by stream size or watershed area (Hill et al., 2003), which are concerns with both macroinvertebrate and fish indices.

Periphyton assessments are, however, limited by natural cycles that impact both the abundance and diversity of algal communities in areas with seasonal change (Bahls, 1993). Additionally, these communities are subject to flushing by high flows, so timing of sampling events is critical. Sampling is restricted, therefore, to periods of relatively stable stream flow, which correspond to late summer and early fall in most areas of the U.S. (Kentucky DEP, 1993; Bahls, 1993). Since algal growth is light-limited, problems can occur in interpreting assessments for heavily shaded streams. Because of their short life-span, the algal communities do not integrate environmental effects over seasons or years, and for that reason, EPA recommends only using algal assessments as a supplement to other biological community assessments (Barbour et al., 1999). Perhaps the greatest limitation, however, is the lack of expertise in most states to perform the detailed algal taxonomic classifications necessary to achieve the total benefits of periphyton assessments (Brumley, 2005).

\section{Macroinvertebrate Community Assessment}

Benthic macroinvertebrates are aquatic organisms without backbones or internal skeletons, including Chironomidae, Ephemeroptera, and Hydropsychidae, that can be seen without a microscope and include aquatic insects, snails, and crayfish. Identification to the species level, however, requires a microscope and some taxonomic experience. Benthic macroinvertebrates spend at least part of their life cycles in and around the stream ecosystem.

Benthic macroinvertebrates are the most common assemblage used for biomonitoring, such that in 2002, all states reported performing some type of benthic macroinvertebrate sampling for bioassessment purposes (EPA, 2002a). The RBP for macroinvertebrates were developed primarily for use in wadeable streams and rivers, and some variation of these protocols is used by the majority of states. Sampling is typically done in those seasons that are expected to have minimal year-to-year natural variations and when targeted species are most accessible. In some regions of the U.S., many low-order streams are intermittent, which complicates sampling. Sampling frequency varies among states from several times a year to only once per each multi-year period used for 305(b) report assessments.

A number of different indices have been developed for use in summarizing and interpreting benthic macroinvertebrate data, including the Invertebrate Community Index (ICI; DeShon, 1995), the RBP (Plafkin et al., 1989; Barbour et al., 1999), the Macroinvertebrate Aggregated Index for Streams (MAIS; Smith and Voshell, 1997), the benthic Index of Biotic Integrity (IBI; Kerans and Karr, 1994), and the Stream Condition Index (SCI; Tetra Tech, 2003), among others. Each of these macroinvertebrate indices consists of a variable number of different metrics intended to measure the richness, composition, tolerance or intolerance, feeding mechanism, and habit of the benthic macroinvertebrate assemblage tailored to their region. In the southeastern coastal plain, the intermittent nature of low-order streams often requires that established indices be modified to account for local condi- 
tions. Davis et al. (2003) found that in southern Georgia, during the intermittent flow period when natural stresses (i.e., stagnant water, high temperatures, low dissolved oxygen) are high, many metrics, such as percentages of dominant family, burrowers, chironomids, and dipterans, become similar at sites ranging from undisturbed to highly disturbed.

The strengths of using macroinvertebrate community assessments include that these assemblages are abundant in most streams, including lower-order streams that may support only a limited fish population. Since macroinvertebrates have limited mobility during their larval stages, they serve as good indicators of localized stream water quality. Their complex life cycles of a year or more integrate the effects of stressors over longer periods of time, such as seasons or years, rather than just at a point in time, as represented by a chemical water sample analysis. Macroinvertebrate sampling is relatively easy to perform, requires few people and inexpensive equipment, and has minimal effect on the total benthic community. Macroinvertebrate assemblages consist of species with a broad range of trophic levels and pollution tolerances that can provide much information for interpreting biological health and environmental stress.

The integration of longer-term impacts in macroinvertebrate indices may also identify waters as impaired that otherwise appear to be meeting water quality standards, as demonstrated in figure 1 . The macroinvertebrate index of biological integrity was computed by the methodology of Chirhart (2003) for the St. Croix River basin in Minnesota. While high IBI scores indicate greater biological integrity, only values corresponding to poor or very poor scores are plotted with respect to dissolved oxygen and total suspended solids. This truncated scale is used to better illustrate the relationship between poor IBI scores, sample concentrations, and the applicable water quality standards. Some samples clearly indicate impairment using the macroinvertebrates indicators, even though they met the standards for dissolved oxygen and total suspended solids. An additional advantage of macroinvertebrate bioindicators is that they integrate stream conditions related to flow and channel characteristics as well as the cumulative impact of multiple potential contaminants.

The interpretation of macroinvertebrate metrics for diagnosing specific causes of impairment, however, consti-
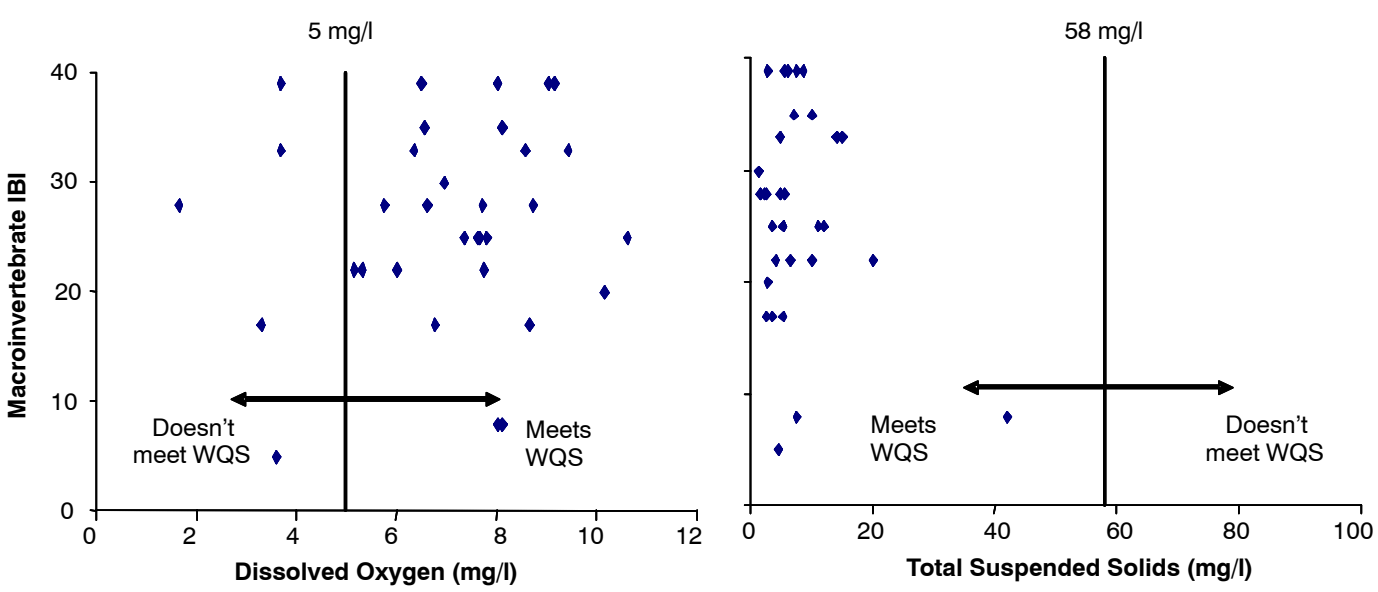

tutes its major limitation. Currently, the recommended EPA diagnostic procedures (EPA, 2000) rely primarily on a weight-of-evidence approach to identify causes of environmental stress. This approach is useful, but the results can be somewhat difficult to interpret in cases where more than one stressor is present and where no one stressor dominates. Therefore, it is usually necessary to employ combinations of procedures or other investigative approaches to identify the causes for the low IBI scores shown in figure 1.

\section{Fish Community Assessment}

Fish are the largest and most mobile of the aquatic biological communities and are at the top of the food chain in the stream ecosystem. While "fish are the aquatic organisms that elicit the highest concern from the public and water resource managers," current fish populations are far from natural, having been "manipulated throughout the history of human settlement in the U.S." (Bryce and Hughes, 2003). As of 2002, approximately 37 states reported using fish as one of the components of their biological assessments (EPA, 2002a).

The principal evaluation mechanism in the RBP for fish utilizes the technical framework of the Index of Biotic Integrity (IBI), a fish assemblage assessment approach developed by Karr (1981). The IBI consists of a variety of species richness, trophic composition, and fish abundance and condition measures, incorporated into a single ecologically based index. This multimetric index framework for rapid bioassessment of fish has served as the basis for index development in many regions and states around the U.S. A compilation of metrics used for index development for a variety of regions and states is given in Barbour et al. (1999), where each index is based on some combination of 61 different fish metrics. A more detailed description of the basis for this approach for fish is presented in Karr et al. (1986) and Ohio EPA (1987). References to regional applications and modifications of this basic approach are also given in Barbour et al. (1999).

Fish sampling is generally performed in mid to late summer when stream flows are moderate to low and less variable than in other seasons and when populations are less migratory. Although various types of equipment are used to sample fish, the same two techniques (electrofishing and seining) are commonly used in wadeable fresh water habitats. Fish sampling procedures typically focus on multiple

Figure 1. Poor macroinvertebrate IBI scores for the St. Croix River basin in Minnesota. 


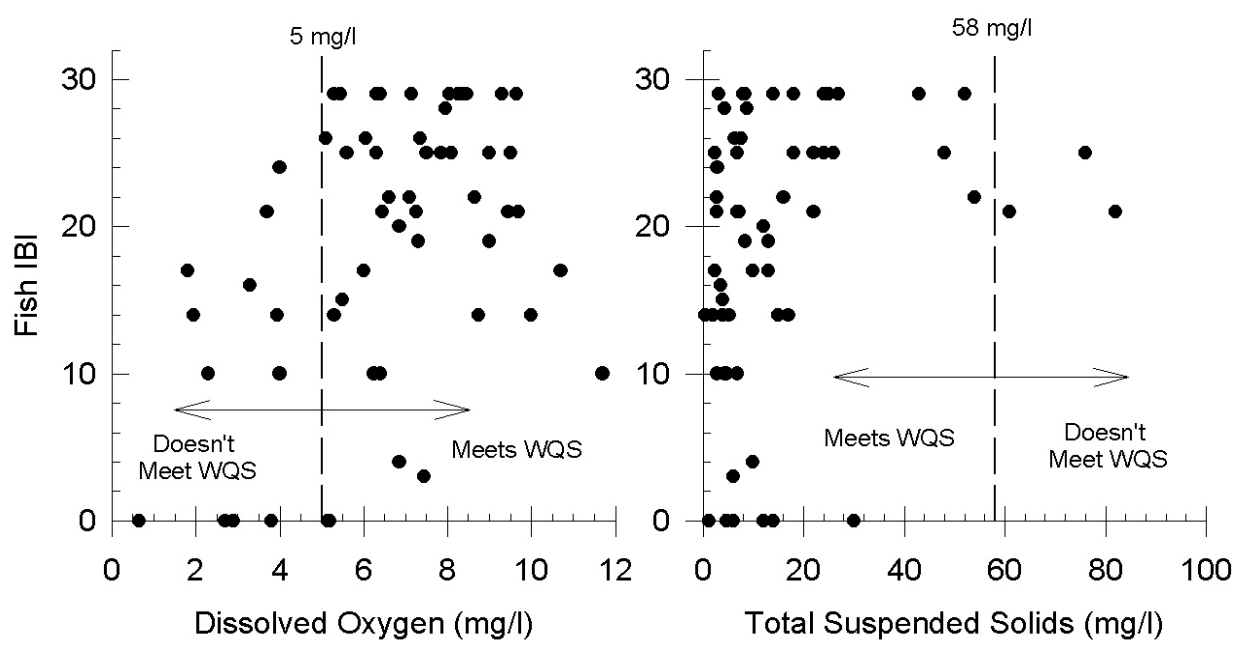

Figure 2. Poor fish IBI scores for the Upper Mississippi River basin in Minnesota.

habitats (riffles, runs, and pools), each sampled in relative proportion to their presence in the sampled stream reach. A habitat assessment is performed, and physical/chemical parameters are measured concurrently with fish sampling in order to document and characterize available habitat within the sample reach (Barbour et al., 1999).

A major strength of using fish in biological assessments is their ability to integrate long-term environmental effects. Long-term effects occur because fish life cycles cover multiple years, and they feed on and bioaccumulate some pollutants from lower trophic levels. Since fish are consumed by humans, they also serve as a direct link between environmental contamination and human health. In addition, since fish account for nearly half of the endangered vertebrate species and subspecies in the U.S., they are also a direct measure of environmental impact (Warren and Burr, 1994). Because of the extensive study of environmental impacts on fish, the environmental requirements of most fish are comparatively well known, making fish community assessment a useful diagnostic tool (Barbour et al., 1999). Fish metrics and indices are also integrators of flow and channel characteristics.

An example of the increased level of impairment detection by a fish index compared with other chemical and physical water quality standards is shown in figure 2 . In this figure, fish IBI values corresponding to poor or very poor scores (indicating impairment) were plotted with respect to observed dissolved oxygen and total suspended solids (which showed only minor exceedences of their respective chemi$\mathrm{cal} /$ physical water quality standards). The fish IBI in this example was computed using the approach of Niemela and Feist (2002) for the upper Mississippi River located upstream of St. Paul, Minnesota.

Similar to the macroinvertebrate IBI, the fish IBI requires additional analysis to define the causes of the impairment. Weight-of-evidence approaches are often used to determine these causes. An analysis performed for one of the sites represented in figure 2 concluded that the most probable cause for the impairment was the loss of habitat resulting from unstable or unsuitable substrates (Lane and Cormier, 2004). The IBI information used to interpret the relationship between fish populations and human disturbances, however, is often confounded by influences of watershed area, proximity to big rivers, introduction of alien species, and put-and-take fisheries (Bryce and Hughes, 2003).

\section{APPLICATION WITHIN A TMDL FRAMEWORK}

\section{Linking Biological Impairments With Pollutants}

While a bioassessment may result in a water body being classified as impaired, a supplemental stressor analysis is usually necessarily to identify the pollutant or stressor that is causing the impairment. The identified pollutant may also be related to an intermediate effect of the biological impairment. A comparison of approaches among states is difficult to make because of the wide variety of terms used to describe biological impairments. EPA has developed the WATERS database (EPA, 2005) to track the status of all impaired stream segments across the U.S. from their original 303(d) listing through the approval of their TMDL studies. In this database, categories of "biological" impairment are referred to with a range of terms based on impacts (biodiversity impacts), criteria used (biological criteria), impairment type (biological, benthic), and suspected pollutant (algal growth/ chlorophyll $a$, nutrients, sediment/siltation). Pollutant descriptions also include flow alteration and habitat alteration. The rationales used by states to justify their linkages are just as diverse.

While modeling is used with many physical and chemical pollutants to link impairment with pollutant levels, the linkages between biological community health and the suspected stressors are much more complex. Models, therefore, are not currently being used to link the complex variety of processes needed to quantify biological impacts for a TMDL. There are several models, however, that have the potential to play a future role in biological TMDLs. In a recent review of models for TMDL development, Shoemaker et al. (2005) cite Aquatox (Park and Clough, 2004) as a model that could support ecological processes such as fish and food chain simulation. They also rated CAEDYM (Computational Aquatic Ecosystem Dynamics Model; Romero et al., 2004) as having high support for ecological modeling. CAEDYM (developed in Australia) describes aquatic ecological dynamics using ordinary differential equations, but it relies on 
linkages with hydrodynamic models not commonly used in the U.S. and so may be difficult to use in TMDL studies. The British RIVPACS (River In-Vertebrate Prediction and Classification System) is another type of statistical ecological model that predicts invertebrate populations based on extensive data from rivers with good quality and can be used to set population targets for streams undergoing ecological stress (Wright et al., 2000). In the U.S., RIVPACS has been used in stream assessments in the Sierra and Cascade mountain ranges in California (Hawkins and Norris, 1997; Hawkins et al., 2000) and in Oregon and Washington (Ostermiller and Hawkins, 2004). Each of these models, however, address only a portion of the larger linkage needed. Currently, a separate analysis must be performed to evaluate how a complex suite of factors impacts the health of a given biological assemblage over time. While this analysis may be fairly straightforward where point sources are dominant, the links between cause and effect are less evident where nonpoint sources dominate. The potential sources of stress to be considered in a typical analysis might include nutrients, sediment, organics, temperature, $\mathrm{pH}$, ammonia, toxics, habitat alterations, and flow alterations.

EPA sets forth recommended procedures for linking biological communities with stressors in the Stressor Identification Guidance Document (EPA, 2000). Many states use this approach to analyze existing chemical, physical, and habitat data to look for trends and associations in spatial and temporal relationships with the biological taxonomic data and related metrics. Comparisons may be made with established water quality standards where applicable, with typical ranges of other parameters, and with elevated ranges of additional suspect parameters from assessments of other impaired segments in the state. Where all data are within a typical range, exhibit no standards violations, and show no trends with RBP ratings, the potential stressors may be eliminated from further consideration. In the majority of nonpoint-source related TMDLs, multiple pollutants will typically show some potential for causing stress to the biological community. In these cases where identification of a single stressor is not obvious, a weight-of-evidence approach is generally used to select the most probable stressor(s) from the remaining potential stressors. The most probable stressor is rarely unambiguous, and a measure of subjectivity and professional judgment is generally involved in the final determination. Sediment is a widespread problem that can impair aquatic biological communities. Excess sediment can reduce available habitat for macroinvertebrates and choke fish spawning areas by filling in the pores in gravel and cobble substrate. Problems caused by sediment, however, are rarely supported by ambient monitoring data, as most sediment movement occurs during stormwater runoff events. Not only does sediment affect available habitat, it usually is also accompanied by attached nutrients, organic matter, and other potential pollutants (Novotny, 2003). Therefore, where no clearly dominant stressor is obvious, sediment is often selected as the most probable stressor for TMDL development, as its control will not only improve habitat, but will also reduce loading from other related pollutants.

In areas where landscapes are rapidly changing due to urbanization, hydrologic modification may be the underlying dominant stressor of the biological community (Boward et al., 1999; EPA, 2006a; Konrad and Booth, 2005). The replacement of forested and agricultural lands with impervi- ous surfaces and highly compacted lawns has resulted in alterations of stormwater runoff hydrographs, creating flashy hydrology in the streams. This flashy hydrology causes scouring of channel bottoms and erosion of stream banks with the eroded sediment being deposited downstream, destroying the benthic macroinvertebrate habitat. In these cases, sediment plays a secondary role in stressing the benthic macroinvertebrate community, while the primary stressor is the hydrologic alteration in the watershed due to urbanization. Even though stormwater management planning can help minimize these hydrologic impacts on the biological community from newly developed lands, it will be difficult to restore hydrology that has already been altered, radically in some cases, to pre-development conditions.

Although all states are performing bioassessments based on at least one assemblage type, studies have found that assessing only one assemblage is, typically, only $80 \%$ effective in discriminating between attainment and non-attainment of a stream's designated use. This finding led to EPA's recommendation that states use multiple assemblages for bioassessment (EPA, 2002a). Where bioassessment is performed using more than one biological community type (e.g., algae, macroinvertebrates, and fish), the situation will inevitably arise, however, where different levels of impairment are indicated by the different communities. For example, the mid-Atlantic states reported in their 305(b) reports for 2000 that an average of $58 \%$ of the total assessed stream lengths were in good condition using their ALU support criteria (primarily based on macroinvertebrates). By contrast, Hill et al. (2003), using the periphyton-based PIBI in an analysis of 272 streams in the same area, found that only $25 \%$ of the streams were in good or excellent condition, indicating that periphyton-based indices may detect additional sources of stress not reflected in the macroinvertebrate indices, an implication also noted in Barbour et al. (1999). Griffith et al. (2005) proposed combining select subsets of metrics from the fish, macroinvertebrate, and periphyton assemblages studied in Rocky Mountain streams into a multi-assemblage, multi-metric index of biotic integrity. Such a multi-assemblage index would simplify interpretation, prevent conflicting indications among assemblages, and maximize the potential for diagnosing the variety of environmental stressors affecting the different assemblages. In fact, use of multiple biological assessments may help to separate the influences of multiple stressors, as each biological community may be responding to different stressors or groups of stressors (Barbour et al., 1999).

\section{Defining a Biological TMDL TARget EndPoint}

Once the most probable stressor or source of impairment is identified, the next step in the TMDL process is to define a TMDL target in terms of that pollutant or stressor. TMDL targets for many biological TMDLs are developed around the identified stressor, usually a surrogate measure, that has been associated in some fashion with the biological impairment. In many TMDLs, these target loads are given in terms of turbidity, total suspended solids (TSS), sediment, nitrogen, phosphorus, or chlorophyll $a$. A modeling approach is used in some states to establish a target load of the identified pollutant based on a reference watershed approach. Two such models used for this approach are the Generalized Watershed Loading Functions (GWLF) model (Haith et al., 1992) in Virginia and Pennsylvania (Evans et al., 2001; Yagow, 2004), 
Table 2. Biological indicators used in numeric biocriteria (EPA, 2002a).

\begin{tabular}{lll}
\hline Entity & Biological Indicator & Target Assemblage \\
\hline Florida & Shannon-Weaver diversity index & Macroinvertebrates \\
\hline Ohio & Index of biotic integrity & Fish \\
& Modified index of well-being & Fish \\
& Invertebrate community index & Macroinvertebrates \\
\hline Oklahoma & Sample composition index & Macroinvertebrates \\
& Fish condition index & Fish \\
\hline $\begin{array}{l}\text { Delaware } \\
\text { River Basin } \\
\text { Commission }\end{array}$ & Shannon-Weiner index & Macroinvertebrates \\
& EPT ${ }^{\text {aa }] \text { index }}$ & Macroinvertebrates \\
[a] \%EPT = percent abundance of the pollution-sensitive orders Ephemer- \\
optera, Plecoptera, and Trichoptera.
\end{tabular}

and the Watershed Characterization System (WCS) sediment tool (EPA, 2006b) in Tennessee and in other EPA Region 4 states. With this approach, the unit area loading simulated from a non-impaired reference watershed defines a non-impaired condition and, when multiplied by the area of the impaired watershed, quantifies the target TMDL pollutant load for the impaired watershed. Illinois has used combinations of the GWLF and BATHTUB models to set receiving waterbody total phosphorus concentration targets, and the SWMM and QUAL2E models to set ammonia-N and TSS targets (Illinois EPA, 2006). Currently, no models have been used to model the impacts of watersheds and pollutants on the biological community directly; in fact, many of the underlying relationships needed for such modeling have not been developed. Use of a model such as Aquatox, however, may provide a better conceptual understanding of the dynamics in the biological community during the TMDL study and implementation planning.

\section{LINKING IMPLEMENTATION WITH BIOLOGICAL RECOVERY}

During implementation, control measures are targeted to address the identified pollutant or stressor, even though there is considerable uncertainty in pollutant identification. While surrogate stressor/pollutant loads identified and modeled in the TMDL study are useful in directing implementation efforts towards major suspected pollutant sources, biological recovery will be documented through biological monitoring and not through attainment of the surrogate stressor/pollutant load.

Since load reductions for TMDL targets are often based on surrogate measures, most states have some other criteria that they use to show that a waterbody no longer has a biological impairment. In other words, the surrogate measures are a guide along the right path, but attainment of the surrogate target loads is not sufficient proof of biological recovery. Some states will use the same multimetric index listing criteria as proof of recovery. In states that have defined biocriteria and incorporated them into state standards (EPA, 2002a), these biocriteria can be used to define biological recovery. Biological indicators that are used by some states as the basis for numeric biocriteria are listed in table 2, while table 3 includes a sampling of biological indicators used by various other states as evidence of biological recovery. These indicators can serve as a basis for endpoints against which biological recovery can be measured.

\section{NeEds, Future Work, AND RECOMMENDATIONS}

As pointed out by the National Research Council (NRC, 2001), the science linking stressors (e.g., chemical pollutants, land use conversion, and hydrologic modification) to biological responses has not been fully developed. This poses a significant challenge for using biological indicators within the TMDL program. The complexity of aquatic ecosystems and the great spatial and temporal variability of the factors that control the system have thwarted efforts to develop a comprehensive mechanistic ecosystem model for predicting biological responses in surface water bodies. The Aquatox model shows promise as a tool to conceptually illustrate links between watershed and land use related change and biological response, but additional work is needed to allow calibration to site-specific data and to develop specific guidelines for use in TMDL studies. NRC (2001) suggests using Bayesian network models to combine elements of mechanistic and empirical models. Other approaches, such as neural networks, should be explored so that a number of physical, chemical, and biological stressors controlling the biological response can be considered simultaneously. Additional future modeling needs for biological TMDLs include development of metrics that link biological community characteristics with individual pollutants, integrated assessment methodology based on multiple biological community types, and development of biological criteria-based water quality standards.

Recovery time is also still an issue. Although many studies have been conducted over the years on impacts of best management practices, we still do not fully understand all of the governing forces causing site-specific lag times between implementation and observed effects. When management controls are placed on human disturbances, the response in the biological community will vary depending on the stressor, the level of impairment, and the type of source control (EPA, 2000). In the case of impairment by sediment, even if sediment sources are reduced to the desired level, it may take years for the stream to stabilize and thus provide the desired restored aquatic habitat. If phosphorus is the stressor,

Table 3. Example biological indicators used to assess biological recovery.

\begin{tabular}{|c|c|}
\hline State & Biological Indicator Target/Endpoint \\
\hline Iowa & $\begin{array}{l}\text { Trophic state index (TSI) linked to total phosphorus, algae, and turbidity; biological community that is not impaired based on listing } \\
\text { criteria of the benthic macroinvertebrate IBI[a] and the fish IBI; chlorophyll and transparency related to algae and turbidity. }\end{array}$ \\
\hline Kansas & Macroinvertebrate biotic index, \%EPT ${ }^{[b]}$; Kansas biotic index, \% cover of waterbody in plant growth. \\
\hline Connecticut & Chlorophyll $a$ \\
\hline Ohio & Qualitative habitat evaluative index (QHEI) supportive of numeric biocriteria. \\
\hline Utah & Shift from blue-green algal dominance, shift from sediment and organic enrichment tolerant macroinvertebrates. \\
\hline Missouri & Fine sediment in pools to be within $10 \%$ of a reference site. \\
\hline
\end{tabular}


then phosphorus that has accumulated in soil and channel sediment may also take years to be flushed from the system. Because biological communities and stream ecosystems are complex entities, their response to environmental variables is rarely linear. In some cases, the biological community may respond quickly to control of sources of pollution or stress, while in other cases, even if implementation proceeds and TMDL target levels of pollutants are achieved, the biological community response still may not achieve the desired level of biological health in a timely fashion. In addition, with many of our watersheds experiencing increasing development and associated hydrologic changes, we need to have a more realistic understanding of achievable levels of restoration. This information is essential in helping to prioritize TMDL implementation efforts and habitat restoration projects.

National policy also plays an important role in the restoration of ecosystem health. Many recommendations and findings in the National Research Council's report on the science behind TMDLs (NRC, 2001) and in EPA's Twenty Needs Report (EPA, 2002b) were never implemented. Karr and Yoder (2004) propose a comprehensive approach to water resource management focused on environmental outcomes that more fully integrates use designation, standards development, monitoring, assessment, and restoration procedures. This approach calls for a more realistic classification of water bodies, consideration of a continuum of biological conditions, inclusion and evaluation of all forms of pollution, and improvement of actions to restore impaired waters, among others. An improved policy framework is essential to more fully utilize the potential of biological indicators in the process of restoring the quality of our nation's waters.

Biological indicators fill a void by detecting water quality impairments arising from combinations of pollutants and conditions not specifically targeted with other monitoring programs. Their use for assessment and development of biological TMDLs can be improved through modeling procedures that better define cause-and-effect relationships, through a better understanding of the limits of restoration, and through a more unified national policy that focuses on restoration.

\section{ACKNOWLEDGEMENTS}

This article is the one of a series of articles developed by members of the USDA-CSREES Regional Project S-1004 "Development and Evaluation of TMDL Planning and Assessment Tools and Processes" and the ASABE SW-21 Hydrology Committee. The authors would like to acknowledge the editorial leadership and coordination provided by R. Muñoz-Carpena, Adel Shirmohammadi, and George Vellidis in this group effort, and the internal review comments and suggestions provided by Drs. Brian Benham and George Vellidis.

\section{REFERENCES}

Ambrose, H. E., M. A. Wilzbach, and K. W. Cummins. 2004. Periphyton response to increased light and salmon carcass introduction in northern California streams. J. North American Benthol. Soc. 23(4): 701-712.
Bahls, L. L. 1993. Periphyton bioassessment methods for Montana streams. Helena, Mont.: Montana Department of Health and Environmental Science, Water Quality Bureau.

Barbour, M. T., J. Gerritsen, B. D. Snyder, and J. B. Stribling. 1999. Rapid bioassessment protocols for use in wadeable streams and rivers: Periphyton, benthic macroinvertebrates, and fish. 2nd ed. EPA 841-B-99-022. Washington, D.C.: U.S. Environmental Protection Agency, Office of Water.

Boward, P., L. D. Teeter, B. G. Lockaby, M. K. Hurd, and T. P. Prochaska. 1999. From the mountains to the sea: The state of Maryland's freshwater streams. EPA 903-R-99-023. Annapolis, Md.: Maryland Department of Natural Resources, Monitoring and Non-Tidal Assessment Division.

Brumley, J. 2005. Kentucky's experience with using diatoms for bioassessment. Powerpoint presentation to the Virginia Department of Environmental Quality, Richmond, Virginia.

Bryce, S. A., and R. M. Hughes. 2003. Variable assemblage responses to multiple disturbance gradients: Case studies in Oregon and Appalachia, USA. In Biological Response Signatures: Indicator Patterns using Aquatic Communities, 539-560. T. P. Simon, ed. Washington, D.C.: CRC Press.

Chirhart, J. 2003. Development of a macroinvertebrate index of biological integrity for rivers and streams of the St. Croix River basin in Minnesota. St. Paul, Minn.: Minnesota Pollution Control Agency, Biological Monitoring Program.

Crumpton, W. G. 1989. Algae in northern prairie wetlands. In Northern Prairie Wetland, 188-203. A. G. van der Valk, ed. Ames, Iowa: Iowa State University Press.

Davis, S., S. Golladay, G. Vellidis, and C. Pringle. 2003. Macroinvertebrate biomonitoring in intermittent coastal plain streams impacted by animal agriculture. J. Environ. Qual. 32(3): 1036-1043.

DeShon, J. E. 1995. Development and application of the invertebrate community index (ICI). In Biological Assessment and Criteria: Tools for Water Resource Planning and Decision Making, 217-243. W. S. Davis and T. P. Simon, eds. Boca Raton, Fla.: Lewis Publishers.

EPA. 2000. Stressor identification guidance document. EPA 822-B-00-025. Washington, D.C.: U.S. Environmental Protection Agency, Office of Water and Office of Research and Development.

EPA. 2002a. Summary of biological assessment programs and biocriteria development for states, tribes, territories, and interstate commissions: Streams and wadeable rivers. EPA 822-R-02-048. Washington, D.C.: U.S. Environmental Protection Agency, Office of Environmental Information and Office of Water.

EPA. 2002b. The twenty needs report: How research can improve the TMDL program. EPA 841-B-02-002. Washington, D.C.: U.S. Environmental Protection Agency, OWOW, Assessment and Watershed Protection Division.

EPA. 2005. Watershed assessment tracking and environmental results: WATERS expert query tool. Washington, D.C.: U.S. Environmental Protection Agency. Available at: www.epa.gov/waters/tmdl/expert_queryhtml. Accessed 26 August 2005.

EPA. 2006a. Urbanization and streams: Studies of hydrologic impacts. Washington, D.C.: U.S. Environmental Protection Agency. Available at: www.epa.gov/OWOW/NPS/urbanize/report.html. Accessed 9 February 2006.

EPA. 2006b. Watershed Characterization System (WCS). Atlanta, Ga.: U.S. Environmental Protection Agency, Region 4. Available at: www.epa.gov/athens/wwqtsc/WCS-toolbox.pdf. Accessed 13 February 2006.

Evans, B. M., S. A. Sheeder, K. J. Corradini, and W. S. Brown. 2001. AVGWLF version 3.2. Users Guide. University Park, Pa.: Pennsylvania State University, Environmental Resources Research Institute; Harrisburg, Pa.: Pennsylvania Department of Environmental Resources, Bureau of Watershed Conservation. 
Gaiser, E. E., D. L. Childers, J. A. Browder, S. M. Davis, and K. C. Tarboton. 2004. Chapter 5: Periphyton habitat suitability index. In Habitat Suitability Indices for Evaluating Water Management Alternatives. South Florida Water Management District. Office of Modeling Technical Report. K. C. Tarboton, M. M. Irizarry-Ortiz, D. P. Loucks, S. M. Davis, and J. T. Obeysekera, eds. Available at: www.sfwmd.gov. Accessed 9 December 2005.

Griffith, M. B., B. H. Hill, A. T. Herlihy, and P. R. Kaufmann. 2002. Multivariate analysis of periphyton assemblages in relation to environmental gradients in Colorado Rocky Mountain streams. J. Phycol. 38(1): 83-95.

Griffith, M. B., B. H. Hill, F. H. McCormick, P. R. Kaufmann, A. T. Herlihy, and A. R. Selle. 2005. Comparative application of indices of biotic integrity based on periphyton, macroinvertebrates, and fish to southern Rocky Mountain streams. Ecol. Indicators 5(2): 117-136.

Haith, D. A., R. Mandel, and R. S. Wu. 1992. GWLF: Generalized Watershed Loading Functions, version 2.0. User's Manual. Ithaca, N.Y.: Cornell University, Department of Agricultural and Biological Engineering.

Hawkins, C. P., and R. H. Norris. 1997. Abstract: Comparison of the ability of multimetric and multivariate assessment techniques to detect biological impairment in mountainous streams of California. Bull. North American Benthol. Soc. 14(1): 96.

Hawkins, C. P., R. N. Norris, J. N. Hogue, and J. W. Feminella. 2000. Development and evaluation of predictive models for measuring the biological integrity of streams. Ecol. Applications 10(5): 1456-1477.

Hill, B. H., F. H. McCormick, A. T. Herlihy, P. R. Kaufmann, R. J. Stevenson, and C. Burch Johnson. 2000. Use of periphyton assemblage data as an index of biotic integrity. J. North American Benthol. Soc. 19(1): 50-67.

Hill, B. H., A. T. Herlihy, P. R. Kaufmann, S. J. DeCelles, and M. A. Vander Borgh. 2003. Assessment of streams of the eastern United States using a periphyton index of biotic integrity. Ecol. Indicators 2(4): 325-338.

Illinois EPA. 2006. Total Maximum Daily Loads: A citizens' guide to achieving water quality. Springfield, Ill: Illinois Environmental Protection Agency, Bureau of Water. Available at: www.epa.state.il.us/water/tmdl/. Accessed 13 February 2006.

Karr, J. R. 1981. Assessment of biotic integrity using fish communities. Fisheries 6(6): 21-27.

Karr, J. R., and C. O. Yoder. 2004. Biological assessment and criteria improve Total Maximum Daily Load decision making. $J$. Environ. Eng. 130(6): 594-604.

Karr, J. R., K. D. Fausch, P. L. Angermeier, P. R. Yant, and L. J. Schlosser. 1986. Assessing biological integrity in running waters: A method and its rationale. Special Publication 5. Springfield, Ill.: Illinois Natural History Survey.

Kelly, M. G. 1998. Use of the trophic diatom index for monitoring eutrophication in rivers. Water Research 32(1): 236-242.

Kentucky DEP. 1993. Methods for assessing biological integrity of surface waters. Frankfort, Ky.: Kentucky Department of Environmental Protection, Division of Water.

Kerans, B. L., and J. R. Karr. 1994. A benthic index of biotic integrity (B-IBI) for rivers of the Tennessee Valley. Ecol. Applications 4(4): 768-785.

Konrad, C. P., and D. B. Booth. 2005. Hydrologic changes in urban streams and their ecological significance. American Fish. Soc. Symp. 47: 157-177.

Lane, C., and S. Cormier. 2004. Screening-level causal analysis and assessment of an impaired reach of the Groundhouse River, Minnesota. Cincinnati, Ohio: EPA, National Exposure Research Laboratory.

Muñoz-Carpena, R., G. Vellidis, A. Shirmohammadi, and W. W. Wallender. 2006. Modeling tools for TMDL development and implementation. Trans. ASABE 49(4): 961-965.

Niemela, S., and M. D. Feist. 2002. Index of biological integrity guidance for coolwater rivers and streams of the Upper
Mississippi River basin. St. Paul, Minn.: Minnesota Pollution Control Agency, Biological Monitoring Program.

NMNH. 2006. Algae: An introduction. Washington, D.C.: Smithsonian Institution, National Museum of Natural History. Available at: www.hrw.com/science/si-science/biology/plants/ algae/Alg-Div.html. Accessed 9 February 2006.

Novotny, V. 2003. Water Quality: Diffuse Pollution and Watershed Management. 2nd ed. Hoboken, N.J.: John Wiley and Sons.

NRC. 2001. Assessing the TMDL approach to water quality management. Washington, D.C.: National Research Council, National Academy Press.

NWCC. 1999. A procedure to estimate the response of aquatic systems to changes in phosphorus and nitrogen inputs. Washington, D.C.: USDA Natural Resources Conservation Service, National Water and Climate Center.

Ohio EPA. 1987. Biological criteria for the protection of aquatic life: Volumes I-III. Columbus, Ohio: Ohio Environmental Protection Agency.

Ostermiller, J. D., and C. P. Hawkins. 2004. Effects of sampling error on bioassessments of stream ecosystems: Application to RIVPACS-type models. J. North American Benthol. Soc. 23(2): 363-382.

Park, R. A., and J. S. Clough. 2004. Aquatox (release 2): Modeling environmental fate and ecological effects in aquatic ecosystems. Volume 2: Technical documentation. EPA 823-R-04-002. Washington, D.C.: U.S. Environmental Protection Agency, Office of Water.

Plafkin, J. L., M. T. Barbour, K. D. Porter, S. K. Gross, and R. M. Hughes. 1989. Rapid bioassessment protocols for use in streams and rivers: Benthic macroinvertebrates and fish. EPA 440-4-89-001. Washington, D.C.: U.S. Environmental Protection Agency, Office of Water Regulations and Standards.

Ponader, K., and D. Charles. 2003. Understanding the relationship between natural conditions and loadings on eutrophication: Algal indicators of eutrophication for New Jersey streams. Final Report Year 2. Report No. 03-04. Philadelphia, Pa.: The Academy of Natural Sciences, Patrick Center for Environmental Research. Available at: www.state.nj.us/dep/dsr/wq/wq.htm. Accessed 9 December 2005.

Ponader, K. C., D. F. Charles, and T. J. Belton. 2006. Diatom-based $\mathrm{TP}$ and TN inference models and indices for monitoring nutrient enrichment of New Jersey streams. Ecol. Indicators (in press).

Prygiel, J., and M. Coste. 1999. Progress in the use of diatoms for monitoring rivers in France. In Use of Algae for Monitoring Rivers III, 165-179. J. Prygiel, B. A. Whitton, and J. Bukowska, eds. Douai, France: Agence de l'eau Artois-Picardie.

Prygiel, J., L. Lévêque, and R. Iserentant. 1996. A new practical diatom index for the assessment of water quality in monitoring networks [in French]. Rev. Sci. Eau 9(1): 97-113.

Romero, J. R., M. R. Hipsey, J. P. Antenucci, and D. P. Hamilton. 2004. Computational aquatic ecosystem dynamics model CAEDYM v2.1. Science manual. Crawley, W. Australia: University of Western Australia, Centre for Water Research.

Shoemaker, L., T. Dai, and J. Koenig. 2005. TMDL model evaluation and research needs. EPA 600-R-05-149. Cincinnati, Ohio: U.S. Environmental Protection Agency, National Risk Management Research Laboratory.

Smith, E. P., and J. R. Voshell, Jr. 1997. Studies of benthic macroinvertebrates and fish in streams within EPA Region 3 for development of biological indicators of ecological condition. Blacksburg, Va.: Virginia Tech.

Tetra Tech. 2003. A stream condition index for Virginia non-coastal streams. Prepared for U.S. EPA Region 3, Wheeling, W.V.; U.S. EPA Office of Science and Technology, Washington, D.C.; and Virginia Department of Environmental Quality, Richmond, Va. Owings Mill, Md.: Tetra Tech, Inc. Available at: www.deq.virginia.gov/watermonitoring/pdf/vastrmcon.pdf.

VAC. 2005. Virginia Administrative Code. Water quality standards. General criteria. Available at: 
leg1.state.va.us/cgi-bin/legp504.exe?000+reg+9VAC25-260-20. Accessed 31 August 2005.

Warren, M. L., Jr., and B. M. Burr. 1994. Status of freshwater fishes of the U.S.: Overview of an imperiled fauna. Fisheries 19(1): 6-18.

Wright, J. F., D. W. Sutcliffe, and M. T. Furse, eds. 2000. Assessing the biological quality of fresh waters: RIVPACS and other techniques. Ambleside, U.K.: Freshwater Biological Association.
Yagow, G. 2004. Using GWLF for development of "reference watershed approach" TMDLs. ASAE Paper No. 042262. St. Joseph, Mich.: ASAE. 